\title{
ナノ電気化学セル顕微鏡を用いた電極表面の局所電気化学測定
}

\author{
熊谷明哉 ${ }^{1,2} \cdot$ 高橋康史 $^{3,4} \cdot$ 三浦千穂 $^{2} \cdot$ 渡邊徹弥 $^{2} \cdot$ 猪又宏貴 $^{2}$ \\ 棟方裕 ${ }^{5} \cdot$ 珠现 $^{2}$ 仁 $^{2}$ 金村聖志 $^{5} \cdot$ 末永智一 $^{1,2}$ \\ ${ }^{1}$ 東北大学原子分子材料科学高等研究機構 函 980-8577 宮城県仙台市青葉区片平 2 丁目 1-1 \\ ${ }^{2}$ 東北大学大学院環境科学研究科 凿 980-0845 宮城県仙台市青葉区荒巻字青葉 6-6 \\ 3金沢大学理工研究域電子情報学系 凿920-1192 石川県金沢市角間町 \\ ${ }^{4} J S T$-さきがけ 函332-0012 埼玉県川口市本町 4-1-8 \\ 5首都大学東京大学院都市環境科学研究科 函 192-0397 東京都八王子市南大沢 1-1
}

（2016 年 8 月 9 日受付；2016 年 8 月 19 日掲載決定）

\section{Localized Electrochemical Analyses on Electrodes Using by Nano-Scanning Electrochemical Cell Microscopy}

\author{
Akichika Kumatani ${ }^{1,2}$, Yasufumi Takahashi ${ }^{3,4}$, Chiho Miura ${ }^{2}$, Tetsuya Watanabe $^{2}$, Hirotaka Inomata ${ }^{2}$, \\ Hirokazu Munakata ${ }^{5}$, Hitoshi ShiKu ${ }^{2}$, Kiyoshi Kanamura ${ }^{5}$ and Tomokazu Matsue ${ }^{1,2}$ \\ ${ }^{1}$ Advanced Institute for Materials Research, Tohoku University, 2-1-1 Katahira, Aoba-ku, Sendai, Miyagi 980-8577 \\ ${ }^{2}$ Tohoku University, 6-6 Aramaki Aoba, Aoba-ku, Sendai, Miyagi 980-0845
}

${ }^{3}$ Division of Electrical Engineering and Computer Science, Kanazawa University, Kakuma-machi, Kanazawa, Ishikawa 920-1192

${ }^{4}$ PRESTO, JST, 4-1-8 Honcho, Kawaguchi, Saitama 332-0012

${ }^{5}$ Tokyo Metropolitan University, 1-1 Minami Ohsawa, Hachioji, Tokyo 192-0397

(Received August 9, 2016 ; Accepted August 19, 2016)

\begin{abstract}
Scanning electrochemical cell microscopy with a single barrel nanopipette (nanoSECCM), which is one of scanning electrochemical microscope (SECM) families, is a powerful tool for analyzing electrochemical activities (e.g. redox reaction and lithium-ion (de) intercalation processes) at localized area. A glass nano-pipette is used as a probe of nanoSECCM filled with electrolyte and a reference electrode. As the pipette is in proximity of sample surface, a meniscus is created. Through the meniscus, electrochemical activities can be obtained at localized area on the sample. Further, as the pipette scans the sample surface, electrochemical activities can be also visualized. Our experiments demonstrate that nanoSECCM is applicable to investigation of current response related to lithium-ion transport, redox cycling on various types of electrodes.
\end{abstract}

KEYWORDS : SPM, SECM, lithium-ion batteries, electrochemistry, redox cycling

\section{1.は じめに}

近年，燃料電池やリチウムイオン電池に代表される電 気化学反応を利用したエネルギー変換・蓄電デバイスの 開発が盛んに行われている。それらデバイス機能性のさ らなる効率化には, 従来のバルク体を用いた電気化学評

E-mail : matsue@bioinfo.che.tohoku.ac.jp, kumatani@bioinfo.che.tohoku.ac.jp
価に留まらず, 電極表面で起こる不均一な電気化学反応 をサブマイクロメートルより高い分解能で定量的な計測 評価法を確立する必要がある。それにより, 電極材料の 結晶方位や結晶粒界および表面構造が電気化学反応に及 ぼす影響を精緻に分類することが可能となり，高機能性 を発現する要因の特定につなげ，材料の設計指針にフィ ードバックすることができる。近年，サブマイクロメー トル以下の電極反応計測手法として走查型プローブ顕微 鏡（SPM）を用いる研究が報告されている。一例とし 
て，米オークリッジ国立研究所の Kalinin らにより開発 された電気化学ストレイン顕微鏡（Electrochemical strain microscope : ESM）がある。ESM においては，測定試料 表面に探針を接触させ周期的な電圧パルスを印加するこ とで試料内のイオンを誘起させ，表面形状に歪み（スト レイン）を生む。その歪みをイオン輸送特性として測定 する。ESM は既に全固体型リチウムイオン電池におけ る正極および負極表面に応用され, 全固体電池の動作前 後で電極の結晶方位と粒界におけるイオン輸送の変化を ナノメートルスケールの分解能で評価し, それらが電池 特性に及ぼす影響を明らかにしている ${ }^{1,2)}$ 。また，電気 化学反応を電流応答として直接評価可能な SPM 技術と して，米テキサス大学の B ard らにより開発された走査 型電気化学顕微鏡 (Scanning electrochemical microscope : SECM $)^{3)}$ による評価法も注目されている。SECM におい ては，半径数マイクロメートルほどの金属細線をガラス などの絶縁体で封止した微小電極を探針として用い，電 解液に浸漬させた試料と探針間で局所的に起こる酸化還 元電流を電極表面の反応性として捉える。電気化学反応 を直接捉えることが可能であるが，試料全体を電解液に 浸漬させ測定を行うため, 試料表面で起こる局所的な電 気化学反応を捉えることは困難であった。近年, 英ウォ ーイック大学の Unwin らは微小電極に代わり $\theta$ 型のガ ラスナノピペットを探針と用いる走查型電気化学セル顕 微鏡（Scanning electrochemical cell microscope : SECCM） の開発に成功した ${ }^{4)}$ 。SECCM においては, ピペットと 測定試料間に微小なメニスカス（セル）を形成させ，こ の微小セル構造を用いて, 電極表面のみで起こる局所的 な電気化学反応の計測を可能とした。また, ピペットの 各側に電解液と参照極を充填し，両参照極間を流れるイ オン電流を一定に保持するようにピペットの高さを制御 することで一定体積のセルを介しての测定を可能として いる。Pt の多結晶薄膜表面の電極反応の不均一性や単 一の金属・半導体カーボンナノチューブまたは, グラフ エンの反応性の違いなどを，高空間分解能を持った顕微 鏡測定で捉えることにより，電気化学反応に関する局所 的な議論が可能となり始めている ${ }^{5 \sim 7)}$ 。我々は, 空間分 解能をさらに高め, ナノメートルスケールにておこる局 所的な電気化学反応を捉えるため SECCM のナノピペッ 卜を従来の $\theta$ 型に替わり，単一バレルで作製し先端径の 微細化を実現したナノ電気化学セル顕微鏡（Scanning electrochemical cell microscopy with a single barrel nanopipette : nanoSECCM) を開発した ${ }^{8)}$ 。ナノ電気化学セル顕 微鏡は, 通常の SECCM とは違い, メニスカス形成時に 計測される容量電流を検出することにより高さを制御し ている。また, 開口径 $50 \mathrm{~nm}$ 以下のピペット作製にも
成功しており, 高分解能を持つ電気化学反応の測定技術 となっている。

本研究では, 局所的な電気化学反応を捉え, それを可 視化するナノ電気化学セル顕微鏡を用いて, 電極表面で 起こる局所的な電気化学反応 : 酸化還元反応とリチウム イオンの挿入・脱離，これらにともなう電流応答の局所 測定とその不均一性の可視化を行うことを目的とした。 酸化還元反応の局所測定には, HOPG 電極を䢃開して得 たグラファイト表面のエッジ・ベーサル面における反応 性の局所測定と可視化をピペット内の電解液に溶解させ たルテニウムイオンの酸化還元反応を利用して行った。 䢃開により，グラファイト表面には，エッジが形成され やすく, 次世代のエネルギー材料として研究が盛んなグ ラフェンの特異な電気化学特性 ${ }^{9,10)}$ の要因解明につなげ ることを目的としている。また，リチウムイオンの挿 入・脱離にともなう電流応答の検出には, リチウムイオ ン電池の正極材料として一般的に用いられるリン酸鉄リ チウム $\left(\mathrm{LiFePO}_{4}\right)$ の二次粒子を混合した合剤複合電極 を用いた。この電極表面で起こるリチウムイオンの伝導 経路を検証することにより, 実用電極の表面で起こるリ チウムイオンの脱離・挿入過程とその反応性を検証し た。これらの測定結果から, サブマイクロメートルスケ ールでおこる電気化学反応の検証にナノ電気化学セル顕 微鏡は有効な計測技術であることがわかった。本論文で は, ナノ電気化学セル顕微鏡による局所的な電気化学反 応の測定と電極表面で起こる反応性の可視化結果を解説 する。

\section{2. 実 験 手 法}

\section{1 ナノ電気化学セル顕微鏡：測定系の構築}

ナノ電気化学セル顕微鏡の概略図を Fig. 1 に示す。測 定に用いたナノピペットは, ボロシリケイトガラスキャ ピラリー (外形 $1.00 \mathrm{~mm}$, 内径 $0.78 \mathrm{~mm}$; GC150F-10,

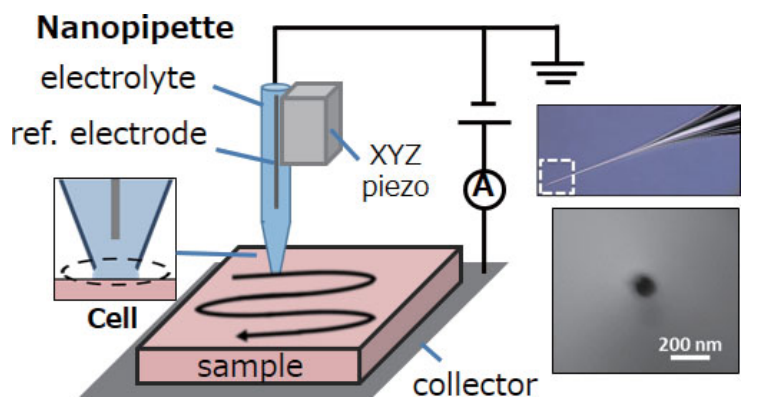

Fig. 1. (color online). A schematic diagram of nanoSECCM and micrographs of a glass nanopipette with $100 \mathrm{~nm}$ in a diameter (inserted). 

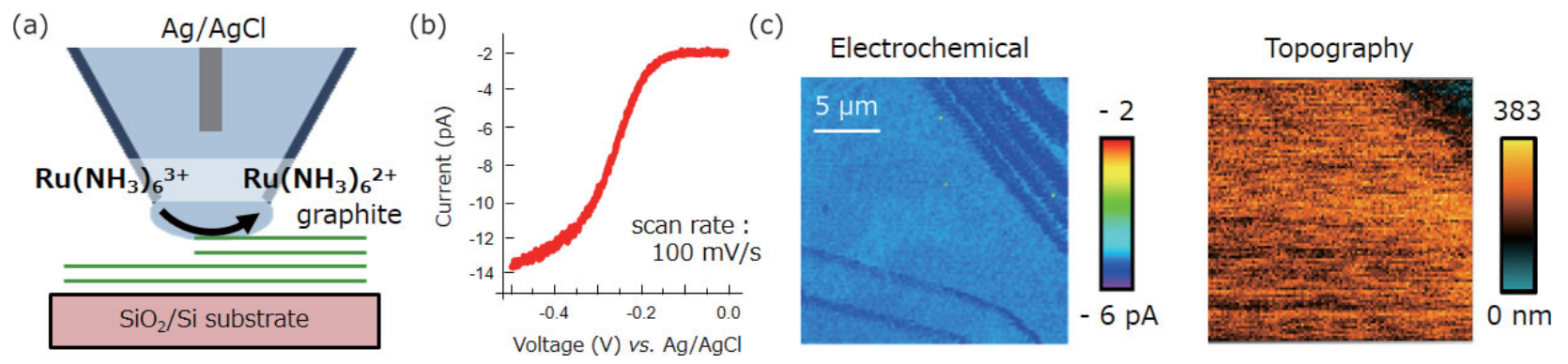

Fig. 2. (color online). (a) A schematic diagram of $\mathrm{Ru}\left(\mathrm{NH}_{3}\right)_{6}{ }^{3+/ 2+}$ on graphite sample through a meniscus by nanoSECCM. (b) LSV result on the cleaved graphite sample. (c) NanoSECCM images at $-450 \mathrm{mV}$ ( $v s . \mathrm{Ag} / \mathrm{AgCl}$ ) : Electrochemical (left) and topographical information (right).

Harvard Apparatus) を $\mathrm{CO}_{2}$ レーザープラー (model P2000, Sutter Instruments）により先尖化し作製した。グラ ファイト試料の測定には, $1 \mu \mathrm{m}$ 程度, リン酸鉄リチウ ムを混合した合剤複合電極試料の測定には，100 nm 程 度の開口径を持つピペットを用いた。電解液には, グラ ファイト試料の場合, $\mathrm{KCl}$ が $25 \mathrm{mM}$ 溶解したリン酸緩 衝整理食塩水 (PBS) に $\mathrm{Ru}\left(\mathrm{NH}_{3}\right)_{6} \mathrm{Cl}_{3}$ を加え, $\mathrm{Ru}$ $\left(\mathrm{NH}_{3}\right)_{6} \mathrm{Cl}_{3}$ の濃度が $5 \mathrm{mM}$ となるよう調整した電解液を 用いた。合剂複合電極には, $3 \mathrm{M} \mathrm{LiCl}$ と $3 \mathrm{M} \mathrm{KCl}$ 水溶液 を用いた。ともに参照極は, $\mathrm{Ag} / \mathrm{AgCl}$ 線を用い, 参照 極と電解液をナノピペットに充填したものをナノ電気化 学セル顕微鏡の探針として用いた。探針の試料へのアプ ローチは, グラファイト試料ではルテニウムイオンが還 元する電位 : $-450 \mathrm{mV}(v s . \mathrm{Ag} / \mathrm{AgCl})$, 合剂複合電極で はリン酸鉄リチウムからリチウムが脱離する電位：650 $\mathrm{mV}$ (vs. $\mathrm{Ag} / \mathrm{AgCl})$ を印加し, メニスカスの形成を行っ た。このメニスカスを介して, 電気化学測定としてリニ アスイープボルタンメトリー (Linear Sweep Voltammetry : LSV）（掃引速度：100 mV/s）とサイクリックボル タンメトリー (Cyclic Voltammetry : CV) (掃引速度 : 10 $\mathrm{mV} / \mathrm{s}$ ) を行い, 各電極試料表面に扔ける電気化学特性 の評価を行った。また，探針を走查することで電極表面 に打ける電気化学反応に起因する電流応答の可視化を行 った。

\section{2 試料作製}

測定に用いた電極試料は，各々以下の手順で作製し た。グラファイト電極は, HOPG（アライアンスバイオ システムズ）を剥離し， $\mathrm{SiO}_{2}$ 基板上に転写した。リン 酸鉄リチウム二次粒子を混合した複合合剤電極は, 導電 助剤であるアセチレンブラック（AB）と結着剤である ポリ塩化ビニルデン $(\mathrm{PVdF})$ を $92: 4: 4 \mathrm{wt} \%=$ $\mathrm{LiFePO}_{4}: \mathrm{AB} ： \mathrm{PVdF}$ にて混合し, N-メチル-2-ピロリ ドンにてスラリー化したものを $\mathrm{Al}$ 集電膜の上に塗布し
合剂複合電極を作製した ${ }^{8,11,12)}$ 。

\section{3. 結 果 と考察}

はじめに, ナノ電気化学セル顕微鏡の探針と電極表面 に形成されるメニスカスを介し, グラファイト電極表面 で起こる電気化学反応を検証した。電極の反応性を示す 指針として, 電解液に含まれる $\mathrm{Ru}\left(\mathrm{NH}_{3}\right)_{6}{ }^{3+/ 2+}$ の酸化還 元反応 $(1)$ を利用した (Fig. 2. (a))。

$$
\mathrm{Ru}\left(\mathrm{NH}_{3}\right)_{6}{ }^{3+}+\mathrm{e}^{-} \rightleftarrows \mathrm{Ru}\left(\mathrm{NH}_{3}\right)_{6}{ }^{2+}
$$

メニスカス形成時に探針を試料表面で固定し，グラフ アイト表面で起こる LSV 測定を行った結果を Fig. 2. （b）に示す。0Vからカソード方向に電極電位を掃引す ると, $-200 \mathrm{mV}$ 程度からルテニウムイオンの 3 価から 2 価への還元反応にともなう電流応答が検出された。ま た, 得られた LSV 結果はメニスカスにより電極の反応 面積が制限されており, 微小電極で得られるシグモイド 型となった ${ }^{13)}$ 。次に, $\mathrm{Ru}\left(\mathrm{NH}_{3}\right)_{6}{ }^{3+}$ が十分還元可能な電 位： $-400 \mathrm{mV}$ (vs. $\mathrm{Ag} / \mathrm{AgCl}$ )を参照極に対して印加さ せ, ナノ電気化学セル顕微鏡で試料表面の反応性を可視 化した。Fig. 2. (c) に同時取得した電気化学応答に起 因した電流応答像（左）と形状像（右）を示す。繴開に より得られたグラファイト表面の平坦性が高くナノ電気 化学セル顕微鏡の高さ分解能 $(5 \mathrm{~nm})$ 以下の領域が多 いため, 形状像からは, 表面構造に起因する高さ情報は ほとんど得られなかった。一方で, $\mathrm{Ru}\left(\mathrm{NH}_{3}\right)_{6}{ }^{3+}$ の還元 応答に起因する電流応答像を見ると直線状に電流応答が 低く観測された。これは，繴開によって生成されたグラ ファイト表面上のエッジに扔ける反応性を検出し，その 反応性が他の領域（ベーサル面）と比較し高いことを示 唆している。エッジにおける高い反応性が観測された要 因として, 酸化還元反応に用いたメデイエーターの酸化 還元電位とグラファイトの状態密度の相関が考えられ $3^{7,14,15)} 。 \mathrm{Ru}\left(\mathrm{NH}_{3}\right)_{6}{ }^{3+/ 2+}$ の酸化還元電位は, グラファイ 
(a)

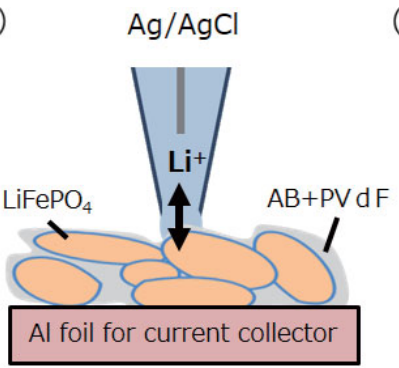

(b)

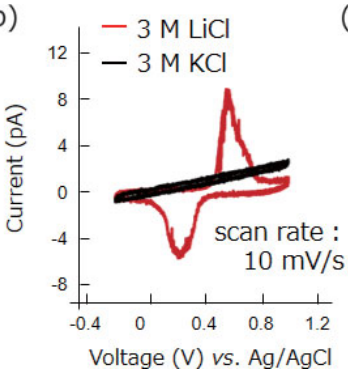

(c)

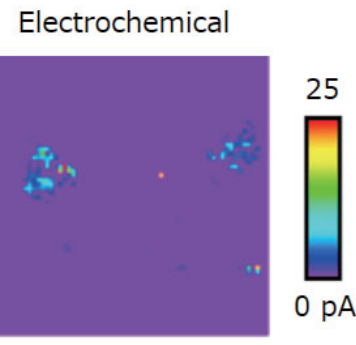

Topography

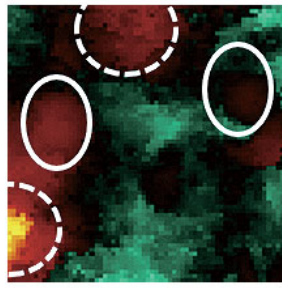

Fig. 3. (color online). (a) A schematic diagram of lithium-ion (de) intercalation processes on $\mathrm{LiFePO}_{4}$ electrodes through a meniscus by nanoSECCM. (b) CV results on $\mathrm{LiFePO}_{4}$ particles by a nanopipette containing either $3 \mathrm{M} \mathrm{LiCl}$ or $3 \mathrm{M} \mathrm{KCl}$. (c) NanoSECCM images at $650 \mathrm{mV}$ (vs. Ag/AgCl), $20 \times 20 \mu \mathrm{m}$ : Electrochemical (left) and topographical information (right)particles circled are active and particles dashed are inactive for lithium-ion deintercalation process.

トもしくはグラフェンのフェルミ準位における状態密度 を反映することがわかっている7,15)。グラフェンの状態 密度を考慮すると, エッジがアームチェア構造を有して いるときに状態密度がジグザグ構造のエッジやベーサル 面と比較し高くなる ${ }^{16,17)}$ 。したがって，本測定で得られ た結果は, グラファイトのエッジにおける電気化学的な 反応性の高さを可視的に示したと考えられる。

次に, リチウムイオン電池の正極材料として多くの研 究がなされているリン酸鉄リチウムを混合した合剤複合 電極を用いて, 測定電極材料内のイオン輸送をナノ電気 化学セル顕微鏡で評価した（Fig. 3. (a))。この測定に 利用したリチウムイオンの扦入・脱離の反応式を( 2 )に 示す。

$\mathrm{Li}_{\mathrm{x}} \mathrm{FePO}_{4}+(1-\mathrm{x}) \mathrm{Li}^{+}+(1-\mathrm{x}) \mathrm{e}^{-} \rightleftarrows \mathrm{LiFePO}_{4}$ ( 2 )

ナノピペットを電極に接触させ, メニスカスを形成し た状態にて，CV 測定を行うと Fig. 3.（b）に示すような リチウムイオンの脱離・挿入にともなう電流応答が, 各々 $650 \mathrm{mV}, 200 \mathrm{mV}$ (vs. $\mathrm{Ag} / \mathrm{AgCl})$ 付近で観測され た。観測された電位は過去の文献の值と一致してい る ${ }^{18)}$ 。また, 電解液を $\mathrm{KCl}$ に替え, 同様の測定を行っ たところ，先程の電流ピークは観測されなかった。した がって, ナノ電気化学セル顕微鏡を用いることで, 電極 表面上で起こるリチウムイオンの挿入・脱離過程に起因 した電流応答を捉えることが可能であることがわかる。

次に, リン酸鉄リチウムからリチウムイオンが脱離す る $650 \mathrm{mV}$ (vs. $\mathrm{Ag} / \mathrm{AgCl})$ において電極表面のナノ電気 化学セル顕微鏡像を取得した（Fig. 3. (c), 左 : 電流応 答像, 右: 形状像)。形状像から電極表面に $\mathrm{LiFePO}_{4}$ の 二次粒子の存在が確認できる。この領域の電量応答像を 見ると枠線で囲まれた二次粒子表面では, 大きな電流応 答が確認でき，一方で，破線の二次粒子は，1．電極表 面に粒子が完全に露呈していない，2．集電体までにイ
オンまたは電子伝導経路が断線されている，3．電極内 部のに高抵抗である，このような要因が考えられ，その 結果，粒子上と思われる領域であっても大きな電流応答 を検出されなかったと考えられる。このように，ナノ電 気化学セル顕微鏡を用いることで電極表面におけるリチ ウム伝導の不均一性と電流経路の検証が可能であり, 高 機能な電池の材料設計指針と電極構造の提案が可能とな る。

\section{4. ま と め}

ナノ電気化学セル顕微鏡の局所電気化学測定を用いる ことで，電極表面でおこる反応性をサブマイクロメート ルスケールで評価することに成功した。グラファイト電 極表面では，ルテニウムイオンの酸化還元反応を利用し エッジ領域において高い電気化学反応性を検出・可視化 した。また, リチウムイオン電池の正極材料表面におい ては, リチウムイオンの挿入・脱離における電流応答に 起因する電流值を検出することで電極表面におけるイオ ン伝導経路の不均一性が明らかになった。ナノ電気化学 セル顕微鏡は局所的な電気化学反応を直接評価すること が可能であり，様々なエネルギーデバイスの検証に有効 である。

\section{謝辞}

本研究は，科学研究費補助金（16H06042，15H05422, $15 \mathrm{~K} 13263,16 \mathrm{H} 00885)$, 独立行政法人科学技術振興機構 (先端計測分析技術・機器開発プログラム, 先端的低炭 素化技術開発 ALCA：蓄電デバイス）および東北大学附 置研究所若手アンサンブルプロジェクトの助成を得て行 われた。 


\section{文献}

1) N. Balke, S. Jesse, A.N. Morozovska, E. Eliseev, D.W. Chung, Y. Kim, L. Adamczyk, R.E. García, N. Dudney and S.V. Kalinin : Nat. Nanotechnol. 5, 749 (2010).

2) N. Balke, S. Jesse, Y. Kim, L. Adamczyk, A. Tselev, I.N. Ivanov, N.J. Dudney and S.V. Kalinin : Nano Lett. 10, 3420 (2010).

3) A.J. Bard, F.R.F. Fan, J. Kwak and O. Lev : Anal. Chem. 61, 132 (1989).

4) N. Ebejer, M. Schnippering, A.W. Colburn, M.A. Edwards and P.R. Unwin : Anal. Chem. 82, 9141 (2010).

5) B.D.B. Aaronson, C. -H. Chen, H. Li, M.T.M. Koper, S.C.S. Lai and Patrick R. Unwin : J. Am. Chem. Soc. 135, 3873 (2013).

6) A.G. Güell, K.E. Meadows, P.V. Dudin, N. Ebejer, J.V. Macpherson and P.R. Unwin : Nano Lett. 14, 220 (2014).

7) A.G. Güell, A.S. Cuharuc, Y.-R. Kim, G. Zhang, S. Tan, N. Ebejer and P.R. Unwin: ACS Nano 9, 3558 (2015).

8) Y. Takahashi, A. Kumatani, H. Munakata, H. Inomata, K. Ito, K. Ino, H. Shiku, P.R. Unwin, Y.E. Korchev, K. Kanamura and T. Matsue : Nat. Commun. 5, 5450 (2014).
9) Y. Wang, Z. Shi, Y. Huang, Y. Ma, C. Wang, M. Chen and Y. Chen : J. Phys. Chem. C 113, 13103 (2009).

10) D.A.C. Brownson, D.K. Kampouris and C.E. Banks : J. Pow. Sour. 196, 4843 (2011).

11) D.Y.W. Yu, C. Fietzek, W. Weydanz, K. Donoue, T. Inoue, H. Kurokawa and S. Fujitani : J. Electrochem. Soc. 154, A253 (2007).

12) H. Nakano, K. Dokko, S. Koizumi, H. Tannai and K. Kanamura : J. Electrochem. Soc. 155, A909 (2008).

13) M.E. Snowden, A.G. Güell, S.C.S. Lai, K. McKelvey, N. Ebejer, M.A. O'Connell, A.W. Colburn and P.R. Unwin : Anal. Chem. 84, 2483 (2012).

14) C.M.A. Brett and A.M.O. Brett : Electrochemistry, Oxford Univ. Press (1993).

15) I. Heller, J. Kong, K.A. Williams, C Dekker and S.G. Lemay : J. Am. Chem. Soc. 128, 7353 (2006).

16) K. Nakada, M. Fujita, G. Dresselhaus and M.S. Dresselhaus : Phys. Rev. B 54, 17954 (1996).

17) Y. Kobayashi, K. Fukui, T. Enoki, K. Kusakabe and Y. Kaburagi : Phys. Rev. B 71, 193406 (2005).

18) C.H. Mi, X.G. Zhang and H.L. Li : J. Electroanal. Chem. 602, 245 (2007). 